\title{
ВИЗНАЧЕННЯ НОРМ ЧАСУ НА ТЕХНІЧНЕ ОБСЛУГОВУВАННЯ ТРАНСПОРТНОГО ЗАСОБУ ДЛЯ ФОРМУВАННЯ ТРУДОМІСТКОСТІ РОБІТ
}

\begin{abstract}
У роботі розглянуті актуальні питання визначення норм часу на обслуговування і ремонт транспортних засобів для формування трудомісткості робіт технічного обслуговування та поточного ремонту рухомого складу підприємств автомобільного транспорту, що використовуватимуться під час їх технологічного розрахунку. На основі існуючих норм часу на виконання різних видів робіт запропоновано граф технічного обслуговування (ремонту) автомобіля за яким розроблено методику визначення норм часу та трудомісткості технічних впливів на автомобіль. Граф технічного обслуговування (ремонту) транспортних засобів служить графічною моделлю для подальших розрахунків норм часу та забезпечує перехід від об'єкта впливу до елементарних операцій. Такий підхід дозволяє розподілити елементарні операції і врахувати особливості їх виконання. Розроблена методика сприяє подальшому розвитку методів визначення трудомісткості технічного обслуговування для технологічного розрахунку підприємств автомобільного транспорту. Проведено аналіз величин трудомісткостей технічного обслуговування транспортних засобів. На прикладі, проведення регламентних робіт з технічного обслуговування нижчого порядку для автобуса за допомогою методів аналізу затрат робочого часу та використовуючи норми часу на слюсарні операції, здійснено орієнтовний розрахунок його сумарної трудомісткості. Отримані результати вказують на скорочення часу виконання операцій технічного обслуговування автобуса, а від так і зменшення встановленої трудомісткості близько 40 \% у порівнянні з нормативом.

Ключові слова: технічне обслуговування, трудомісткість, технологічний розрахунок, автотранспортне підприємство.
\end{abstract}

\section{ВСТУП}

Питання нормування трудомісткості на технічне обслуговування i ремонт колісних транспортних засобів є завжди актуальним, оскільки залежить від особливостей конструкції і експлуатації оновленого і удосконаленого рухомого складу. Вдосконалення конструкції автомобілів відбувається дуже динамічно, змінюючи структуру і обсяги робіт у процесах технічного обслуговування і ремонту. Нормативи трудовитрат на виконання робіт з ТО і ремонту оновлених моделей i модифікацій використовуються фірмовим автосервісом і зазвичай мають обмежений доступ, можуть бути досить укрупненими, а інколи взагалі відсутні. Ті нормативи, з якими можна ознайомитися, часто значно відрізняються від норм технологічного проектування підприємств автомобільного транспорту. Особливо гостро ця проблема постає у випадку експлуатації транспортних засобів, які виготовляються в нашій країні, зокрема автобусів.

\section{АНАЛІЗ ЛІТЕРАТУРНИХ ДАНИХ ТА ПОСТАНОВКА ПРОБЛЕМИ}

Відповідно до Правил надання послуг 3 технічного обслуговування і ремонту колісних транспортних засобів [1] виконавець повинен надати замовнику наряд-замовлення на надання послуг 3 технічного обслуговування і ремонту колісного транспортного засобу, який, окрім іншого, повинен містити інформацію стосовно трудомісткості послуги. У Положенні про технічне обслуговування i ремонт дорожніх транспортних засобів автомобільного транспорту [2] містяться нормативи трудомісткості робіт за видами технічного обслуговування для класів автомобілів різного типу. Порівняння нормативів наведених у [2] та тих, що використовуються фірмовим сервісом, свідчить про значну розбіжність трудовитрат (таблиця 1).

Таблиця 1 - Порівняння нормативів трудомісткості робіт з технічного обслуговування де яких автомобілів

\begin{tabular}{|l|c|c|c|c|}
\hline \multirow{2}{*}{\multicolumn{1}{|c|}{ Колісні транспортні засоби тип, клас }} & \multicolumn{4}{|c|}{ Трудомісткість } \\
\cline { 2 - 5 } & 3а даними [2] & За даними фірмового автосервісу \\
\cline { 2 - 5 } & ТО - 1 & ТО - 2 & ТО - 1 & ТО - 2 \\
\cline { 2 - 5 } & \multicolumn{3}{|c|}{ люд-год на одне обслуговування } \\
\hline Легкові автомобілі & 2,0 & 7,5 & $1,1 \ldots 2,1$ & $1,7 \ldots 4,5$ \\
\hline $\begin{array}{l}\text { Особливо малого класу } \\
\text { (робочий об'єм двигуна до 1,2 л) }\end{array}$ & & & & \\
\hline
\end{tabular}




\begin{tabular}{|c|c|c|c|c|}
\hline \multirow{4}{*}{ Колісні транспортні засоби тип, клас } & \multicolumn{4}{|c|}{ Трудомісткість } \\
\hline & \multicolumn{2}{|c|}{ За даними [2] } & \multicolumn{2}{|c|}{ За даними фірмового автосервісу } \\
\hline & TO - 1 & TO - 2 & TO - 1 & TO - 2 \\
\hline & \multicolumn{4}{|c|}{ люд-год на одне обслуговування } \\
\hline $\begin{array}{l}\text { Малого класу } \\
\text { (робочий об'єм двигуна від } 1,2 \text { до } 1,8 \text { л) }\end{array}$ & 2,3 & 9,2 & $0,9 \ldots 2,9$ & $1,6 \ldots 4,0$ \\
\hline $\begin{array}{l}\text { Середнього класу } \\
\text { (робочий об'єм двигуна від } 1,8 \text { до } 3,5 \text { л) }\end{array}$ & 2,9 & 11,7 & $1,0 \ldots 2,9$ & $1,6 \ldots 4,2$ \\
\hline Вантажні бортові автомобілі з дизелями вантажністю до 8,0 т & 3,4 & 13,8 & $0,7 \ldots 1,5$ & $1,8 \ldots 3,2$ \\
\hline Автомобілі-тягачі. Маса напівпричепа з вантажем до 26,0 т & 3,85 & 16,17 & $3,0 \ldots 5,4$ & $7,4 \ldots 8,8$ \\
\hline
\end{tabular}

Нормативи трудомісткості поточного ремонту, зазвичай, є диференційованими за виконанням окремих робіт. Аналіз нормативів питомої трудомісткості ремонту часто є утрудненим через їх відсутність, недостатність інформації та потребою збору і обробки статистичних даних. Дані наведені у таблиці 1 свідчать про необхідність диференційованого підходу щодо визначення трудомісткості технічного обслуговування колісних транспортних засобів.

Про необхідність обгрунтування величини трудомісткостей робіт 3 технічного обслуговування та ремонту автомобілів, під час технологічного розрахунку, через розбіжності у нормативах, йдеться, зокрема, у роботах $[3,4]$. У роботі [5] проведений аналіз методів технологічного розрахунку підприємств автомобільного транспорту, демонструє визначення нормативів трудомісткості за відомими методами. В основному дослідження орієнтовані на розробку, 3 можливістю подальшої оптимізації, моделей розрахунку трудомісткості робіт 3 технічного обслуговування та ремонту автомобілів чи дослідження обсягів цих робіт [3-8]. В основі формування трудомісткостей виконання технічних впливів $\epsilon$ норми часу на проведення певних робіт та окремих операцій. Важливість нормативного забезпечення процесів технічного обслуговування і ремонту підтверджується результатами досліджень наведеними у $[9,10]$.

\section{ЦІЛЬ ТА ЗАДАЧІ ДОСЛІДЖЕННЯ}

Метою роботи $є$ подальший розвиток методів розрахунку технічно обгрунтованих норм часу 3 технічного обслуговування та ремонту колісних транспортних засобів шляхом розробки методики 3 використанням диференційованих нормативів на окремі операції для певних видів робіт на прикладі технічного обслуговування автобуса. Для досягнення поставленої мети вирішувалися наступні задачі:

- проаналізувати існуючі методи визначення норм часу на виконання технічних впливів;

- розробити порядок розрахунку норм часу на виконання робіт з технічного обслуговування і ремонту автомобілів;

- удосконалити методику розрахунку норм часу на виконання робіт 3 технічного обслуговування і ремонту автомобілів.

\section{РЕЗУЛЬТАТИ ДОСЛІДЖЕНЬ}

Аналіз літературних джерел вказує, що визначення норм часу на виконання слюсарномеханічних, розбирально-збиральних та інших робіт технічного обслуговування i ремонту транспортних засобів зазвичай здійснюється методом безпосереднього вимірювання та методом моментних спостережень, 3 використанням хронометражних, фотохронометражних способів дослідження [11]. На основі статистичних даних прийняті нормативи часу на операції слюсарної обробки деталей та слюсарно-збиральні роботи для дрібносерійного та одиничного виробництва [12]. Таким чином задача зводиться до розробки моделі розрахунку норм часу, 3 можливістю їі адаптації для певних видів робіт та типів транспортних засобів.

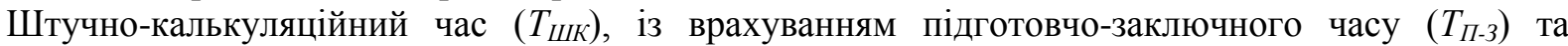
штучного $\left(T_{\amalg}\right)$, визначиться [11]:

$$
T_{\text {ШК }}=T_{\Pi-3}+T_{\amalg \amalg}=T_{\Pi-3}+\left(T_{\text {Обсл }}+T_{\text {ОП }}+T_{\text {ВОс }}\right)=T_{\Pi-3}+T_{\text {Обсл }}+\left(T_{O}+T_{\text {д }}\right)+\left(T_{B}+T_{O c}\right)
$$

де $T_{П-3}, T_{\amalg}-$ час підготовчо-заключних робіт та штучний час, відповідно;

$T_{\text {Обсл }}, T_{O П}, T_{B O c}$ - складові штучного часу: час обслуговування робочого місця, оперативний час, час на відпочинок та особисті потреби, відповідно;

$T_{O}, T_{д}-$ складові оперативного часу: основний та допоміжний, відповідно;

$T_{B}, T_{O c}-$ час на відпочинок та особисті потреби, відповідно. 
У збірнику норм часу на технічне обслуговування i ремонт автомобілів і автобусів використовується методика для визначення норми часу $T$ на одиницю об' єму роботи, виконану одним

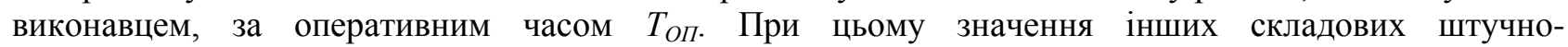
калькуляційного часу: $T_{\Pi \text {-зз }}, T_{O б c}, T_{B}$ та $T_{O c}$, визначаються відсотковим значенням від оперативного часу [13]:

$$
T=T_{\text {ОП }} \cdot\left(1+\frac{t_{\Pi-3}+t_{O б с л}+t_{B}+t_{O c}}{100}\right), \text { (люд.-год) }
$$

де $t_{\Pi-3}, t_{O б с л}, t_{B}, t_{O c}-$ відсоткові значення складових штучно-калькуляційного часу, що доповнюють операційний, \% від $T_{\text {ОП. }}$

Відповідно до [12] оперативний час $\left(T_{O П}\right)$ виконання певного виду робіт (операцій) визначається за залежністю:

$$
T_{\text {OП }}=T_{H} \cdot n \cdot k_{\kappa}=T_{H} \cdot n \cdot k_{y} \cdot k_{c} \cdot k_{\partial} \cdot k_{n p} \cdot k_{n}
$$

де $T_{H}$ - норма калькуляційного часу;

$n$ - кількість однакових операцій або деталей;

$k_{\kappa}-$ коефіцієнт коригування який враховує особливості умов виконання роботи (операції):

$$
k_{\kappa}=k_{y} \cdot k_{c} \cdot k_{\partial} \cdot k_{n p} \cdot k_{n}
$$

$k_{y}-$ коефіцієнт, який враховує умови роботи (положення) виконавців;

$k_{c}-$ коефіцієнт, який залежить від складності операції або вузла автомобіля, який розбирається (збирається);

$k_{\partial}$ - коефіцієнт, який враховує умови доступу до вузла, агрегату, деталі для виконання відповідних видів робіт;

$k_{n p}$ - коефіцієнт приведення норм часу на збиральні роботи до норм часу на розбиральні роботи;

$k_{n}$ - коефіцієнт повторюваності, що враховує ймовірність додаткового виконання частини операції, що не $\epsilon$ контрольною.

Час оперативний на виконання певного виду технічного обслуговування $T_{T O} 3$ врахуванням залежності (3) можна представити наступною залежністю:

$$
T_{O \Pi}^{T O}=\sum_{i=1}^{j} T_{O \Pi i}=\sum_{i=1}^{j} T_{H} \cdot n \cdot k_{\kappa}=\sum_{i=1}^{j} T_{H} \cdot n \cdot k_{y} \cdot k_{c} \cdot k_{\partial} \cdot k_{n p} \cdot k_{n}
$$

Оскільки регламенти робіт з технічного обслуговування та/або ремонту колісних транспортних засобів, їх систем, вузлів та агрегатів значно відрізняються обсягом, переліком та трудомісткістю залежно від ряду факторів доцільно їх представити у формі графу, який наведено на рисунку 1.

Наведений на рисунку 1 граф відображає процес проведення технічного впливу на автомобіль.

Нульовий рівень містить оперативний час, який затрачається на виконання однієї елементарної операції. Під елементарної операцією розуміється окремий прийом, що застосовується під час виконання завдання. Рівень один характеризує кількість однакових прийомів, які застосовуються в технологічному процесі. Рівень 2 описує місце виконання операції, що в свою чергу визначає коефіцієнт $k_{y}$ (умови роботи виконавців) та коефіцієнт $k_{\partial}$ (складність доступу до вузла, агрегату, деталі для виконання відповідних видів робіт).

Рівень 3 визначає перелік операцій, які необхідно виконати під час виконання робіт по технічному обслуговуванню та ремонту. Між рівнем 2 та 3 існують взаємозв'язки, максимальна кількість яких рівна добутку кількості операцій та кількість можливих місць їх виконання. Рівень 4 визначає об'єкт впливу, тобто вузол, систему або агрегат автомобіля, що в свою чергу впливає на значення коефіцієнта $k_{c}$.

Розрахунок норм часу виконання робіт з ТО і ремонту повинен здійснюватися в наступній послідовності: 
- визначення виду обслуговування (рівень 5);

- визначення переліку об'єктів впливу (рівень 4);

- визначення виду операцій по кожному об'єкту впливу (рівень 3);

- визначення місць виконання операцій (рівень 2);

- визначення кількості точок впливу (рівень 1);

- визначення часу виконання однієї елементарної операції (рівень 0)

- розрахунок часу виконання робіт за залежністю (5), (рівень 0-5).

Рівень 5

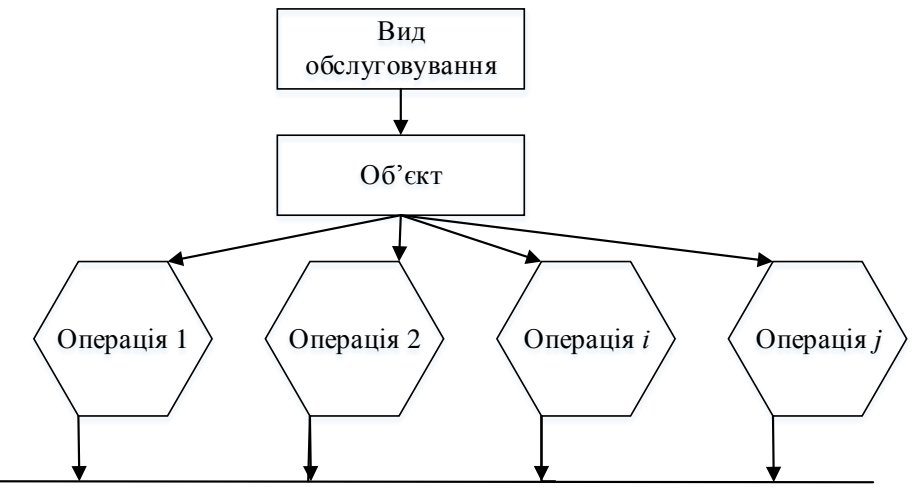

Взаємозв’язки

Рівень 2

Рівень 4

Рівень 3

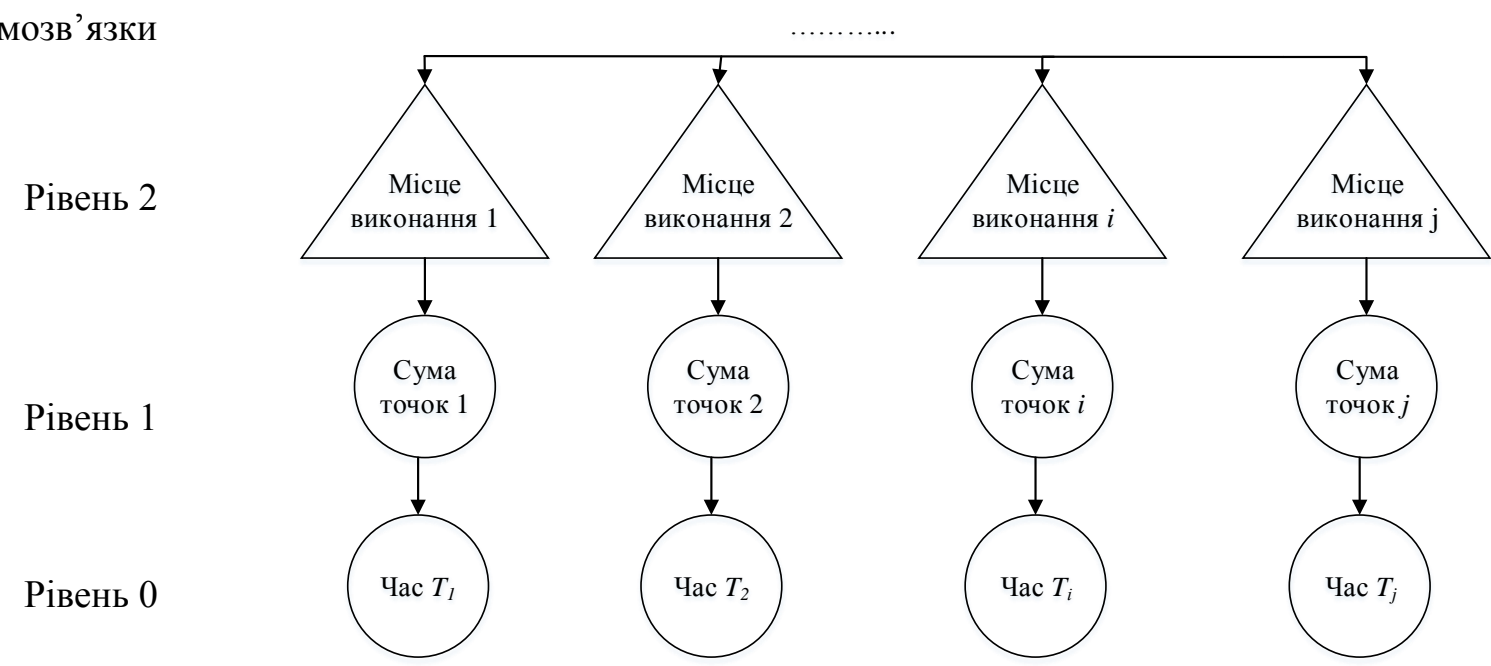

Рисунок 1 - Граф технічного обслуговування (ремонту) автомобіля

За запропонованою методикою здійснено розрахунок трудомісткості ТО-1 (ТO-20000) для автобуса А 22112. Згідно [15] складено перелік робіт (табл. 2).

Таблиця 2 - Регламент робіт ТО-20000 автобуса А 22112

\begin{tabular}{|c|c|c|c|c|c|c|}
\hline № & Найменування об’єкта впливу & $\begin{array}{l}\text { Операції ТО-1 } \\
\text { (ТО-20000) }\end{array}$ & $\begin{array}{l}\text { Місце виконання } \\
\text { робіт }\end{array}$ & $\begin{array}{c}\text { Кількість } \\
\text { точок }\end{array}$ & \begin{tabular}{|c|} 
Час на \\
виконання \\
операції, \\
хв \\
\end{tabular} & $\begin{array}{c}\text { Сумарний } \\
\text { час, хв }\end{array}$ \\
\hline & СИСТЕМИ ДВИГУНА & & & & & \\
\hline 1 & Рідина системи охолодження & $\Pi$ & $\begin{array}{l}\text { Моторний відсік, } \\
\text { зверху }\end{array}$ & 1 & 0,5 & 0,5 \\
\hline 2 & Олива і фільтр системи мащення двигуна & 3 & $\begin{array}{l}\text { Моторний відсік, } \\
\text { зверху }\end{array}$ & 1 & 20 & 20 \\
\hline 3 & Паливний фільтр (попередній і основний) & 3 & $\begin{array}{l}\text { Моторний відсік, } \\
\text { зверху }\end{array}$ & 2 & 4 & 8 \\
\hline 4 & $\begin{array}{l}\text { Перевірка герметичності систем мащення, } \\
\text { живлення паливом і повітрям }\end{array}$ & $\Pi$ & $\begin{array}{l}\text { Моторний відсік, } \\
\text { зверху, знизу }\end{array}$ & 6 & 0,5 & 3 \\
\hline 5 & Повітряний фільтр, продувка & $\Pi$ & $\begin{array}{l}\text { Моторний відсік, } \\
\text { зверху }\end{array}$ & 1 & 2 & 2 \\
\hline 8 & Перевірка роботи моторного гальма & $\Pi$ & Місце водія & 1 & 1 & 1 \\
\hline
\end{tabular}


() Дембіцький В.М., Павлюк В.I. 2020

\begin{tabular}{|c|c|c|c|c|c|c|}
\hline № & Найменування об’єкта впливу & $\begin{array}{l}\text { Операції ТО-1 } \\
\text { (ТО-20000) }\end{array}$ & $\begin{array}{l}\text { Місце виконання } \\
\text { робіт }\end{array}$ & $\begin{array}{c}\text { Кількість } \\
\text { точок }\end{array}$ & \begin{tabular}{|c|} 
Час на \\
виконання \\
операції, \\
хв
\end{tabular} & $\begin{array}{l}\text { Сумарний } \\
\text { час, хв }\end{array}$ \\
\hline 10 & $\begin{array}{l}\text { Перевірка натяжки приводних пасів генератора, } \\
\text { компресора, водяної помпи }\end{array}$ & $\Pi$ & $\begin{array}{l}\text { Моторний відсік, } \\
\text { зверху }\end{array}$ & 1 & 1 & 1 \\
\hline \multirow[t]{2}{*}{11} & $\begin{array}{l}\text { Діагностика електронних систем двигуна і } \\
\text { системи AdBlue }\end{array}$ & $\Pi$ & Місце водія & 4 & 10 & 40 \\
\hline & TPАНСMICIЯ & & & & & \\
\hline 1 & Олива КПП & $\Pi$ & $\begin{array}{l}\text { Моторний відсік, } \\
\text { зверху }\end{array}$ & 1 & 0,5 & 0,5 \\
\hline 2 & $\begin{array}{l}\text { Перевірка вільного ходу педалі зчеплення, } \\
\text { працездатність системи зчеплення }\end{array}$ & $\Pi$ & Місце водія & 1 & 2 & 2 \\
\hline 3 & Робоча рідина приводу зчеплення & $\Pi$ & Місце водія & 1 & 1 & 1 \\
\hline 4 & Змащування витискного підшипника і вилки & 3м & $\begin{array}{l}\text { Моторний відсік, } \\
\text { знизу }\end{array}$ & 2 & 2 & 4 \\
\hline 5 & $\begin{array}{l}\text { Перевірка кріплення фланців і проміжної опори } \\
\text { карданного валу }\end{array}$ & $\Pi$ & Знизу автобуса & 3 & 0,5 & 1,5 \\
\hline 6 & $\begin{array}{l}\text { Змащування хрестовин, шліців і проміжної } \\
\text { опори карданного валу }\end{array}$ & Зм & Знизу автобуса & 4 & 1 & 4 \\
\hline \multirow[t]{2}{*}{7} & $\begin{array}{l}\text { Перевірка роботи механізму перемикання } \\
\text { передач }\end{array}$ & $\Pi$ & Місце водія & 1 & 1 & 1 \\
\hline & АГРЕГАТИ ХОДОВОЇ ЧАСТИНИ & & & & & \\
\hline 1 & Перевірка оливи редуктора ведучої осі & $\Pi$ & Знизу автобуса & 1 & 1 & 1 \\
\hline 2 & $\begin{array}{l}\text { Очищення сапуна ведучого моста, перевірка } \\
\text { герметичності ущільнень }\end{array}$ & $\Pi$ & Знизу автобуса & 2 & 1 & 2 \\
\hline 3 & Змащування пальців ресор & $3 \mathrm{M}$ & Знизу автобуса & 4 & 1 & 4 \\
\hline 4 & $\begin{array}{l}\text { Перевірка підшипників маточин передньої та } \\
\text { задньої осей }\end{array}$ & $\Pi$ & Збоку автобуса & 4 & 1 & 4 \\
\hline 5 & Змащування шкворнів & 3м & Знизу автобуса & 2 & 1 & 2 \\
\hline \multirow[t]{2}{*}{6} & Перевірка затяжки колісних гайок & $\Pi$ & Збоку автобуса & 24 & 0,5 & 12 \\
\hline & КЕРМОВЕ КЕРУВАННЯ & & & & & \\
\hline 1 & $\begin{array}{l}\text { Перевірка рівня рідина системи } \\
\text { гідропідсилювача кермового керування }\end{array}$ & $\Pi$ & $\begin{array}{l}\text { Моторний відсік, } \\
\text { зверху }\end{array}$ & 1 & 1 & 1 \\
\hline 2 & $\begin{array}{l}\text { Герметичність системи гідравлічного } \\
\text { підсилювача кермового керування }\end{array}$ & $\Pi$ & $\begin{array}{l}\text { Моторний відсік, } \\
\text { зверху }\end{array}$ & 1 & 1 & 1 \\
\hline 3 & Вільний хід кермового колеса & $\Pi$ & Місце водія & 1 & 2 & 2 \\
\hline 4 & Змащування наконечників кермових тяг & $3 \mathrm{M}$ & Знизу автобуса & 3 & 1 & 3 \\
\hline \multirow[t]{2}{*}{5} & $\begin{array}{l}\text { Перевірка плавності роботи кермового } \\
\text { керування }\end{array}$ & $\Pi$ & Місце водія & 1 & 1 & 1 \\
\hline & ГАЛЬМІВНА СИСТЕМА & & & & & \\
\hline 1 & Змащування кулаків гальмівних механізмів & 3м & Знизу автобуса & 4 & 1 & 4 \\
\hline 2 & Перевірка герметичності пневмосистеми & $\Pi$ & $\begin{array}{l}\text { Знизу та збоку } \\
\text { автобуса }\end{array}$ & 2 & 0,5 & 1 \\
\hline 3 & $\begin{array}{l}\text { Перевірка стану гальмівних накладок, } \\
\text { барабанів, дисків }\end{array}$ & $\Pi$ & Збоку автобуса & 8 & 0,5 & 4 \\
\hline \multirow[t]{2}{*}{4} & Перевірка стоянкового гальма & $\Pi$ & Місце водія & 1 & 2 & 2 \\
\hline & ПНЕВМОСИСТЕМА & & & & & \\
\hline 1 & $\begin{array}{l}\text { Перевірка кріплення компресора, регуляторів } \\
\text { рівня підлоги, ресиверів, трубопроводів }\end{array}$ & $\Pi$ & $\begin{array}{l}\text { Знизу та збоку } \\
\text { автобуса }\end{array}$ & 14 & 0,5 & 7 \\
\hline 2 & $\begin{array}{l}\text { Перевірка величини спрацьовування регулятора } \\
\text { тиску системи }\end{array}$ & $\Pi$ & Місце водія & 1 & 1 & 1 \\
\hline 3 & Перевірка стану пневморесор & $\Pi$ & Знизу автобуса & 4 & 1 & 4 \\
\hline \multirow[t]{2}{*}{4} & $\begin{array}{l}\text { Перевірка механізмів приводу відкривання } \\
\text { дверей }\end{array}$ & $\Pi$ & Салон автобуса & 2 & 1 & 2 \\
\hline & ПІДВІСКА & & & & & \\
\hline 1 & Перевірка амортизаторів на підтікання & $\Pi$ & Знизу автобуса & 4 & 0,5 & 2 \\
\hline
\end{tabular}


() Дембіцький В.М., Павлюк В.I. 2020

\begin{tabular}{|c|c|c|c|c|c|c|}
\hline № & Найменування об’єкта впливу & $\begin{array}{l}\text { Операції ТО-1 } \\
\text { (ТО-20000) }\end{array}$ & $\begin{array}{c}\text { Місце виконання } \\
\text { робіт }\end{array}$ & $\left|\begin{array}{c}\text { Кількість } \\
\text { точок }\end{array}\right|$ & \begin{tabular}{|c|} 
Час на \\
виконання \\
операції, \\
хв
\end{tabular} & $\begin{array}{l}\text { Сумарний } \\
\text { час, хв }\end{array}$ \\
\hline 2 & $\begin{array}{l}\text { Перевірка стану гумових і гумово-металевих } \\
\text { шарнірів передньої і задньої підвісок, } \\
\text { пневмобалонів }\end{array}$ & $\Pi$ & Знизу автобуса & 8 & 0,5 & 4 \\
\hline 3 & Перевірка стану ресор & $\Pi$ & Знизу автобуса & 2 & 1 & 2 \\
\hline \multirow[t]{2}{*}{4} & $\begin{array}{l}\text { Моменти затяжки різьбових з'єднань передньої } \\
\text { і задньої підвісок }\end{array}$ & $\Pi$ & Знизу автобуса & 12 & 0,5 & 6 \\
\hline & ЕЛЕКТРООБЛАДНАННЯ & & & & & \\
\hline 1 & $\begin{array}{l}\text { Перевірка роботи систем освітлення, звукової і } \\
\text { світлової сигналізації }\end{array}$ & $\Pi$ & Місце водія & 8 & 0,2 & 1,6 \\
\hline 2 & $\begin{array}{l}\text { Перевірка роботи панелі приладів і } \\
\text { склоочисників }\end{array}$ & $\Pi$ & Місце водія & 1 & 0,2 & 0,2 \\
\hline \multirow[t]{2}{*}{3} & $\begin{array}{l}\text { Перевірка кріплення клем генератора, стартера, } \\
\text { акумуляторної батареї }\end{array}$ & $\Pi$ & Збоку автобуса & 6 & 0,5 & 3 \\
\hline & КУЗОВ & & & & & \\
\hline 1 & $\begin{array}{l}\text { Перевірка стану стекол, дзеркал, зовнішнього } \\
\text { виду }\end{array}$ & $\Pi$ & Збоку автобуса & 18 & 0,2 & 3,6 \\
\hline 2 & Перевірка роботи системи вентиляції і обігріву & $\Pi$ & $\begin{array}{l}\text { Місце водія, салон } \\
\text { автобуса }\end{array}$ & 6 & 1 & 6 \\
\hline \multirow[t]{2}{*}{3} & Змащування дверних механізмів & $3 \mathrm{M}$ & Салон автобуса & 4 & 1 & 4 \\
\hline & & $\begin{array}{l}\text { П- перевірити; } \\
\text { 3- - амінити; } \\
\text { 3м - змастити }\end{array}$ & Всього & 179 & 71,6 & 179,9 \\
\hline
\end{tabular}

Під час визначення часу на виконання операцій враховано застосування відповідних засобів автоматизації робочого процесу.

Великий вплив на час виконання робіт має положення працівника. Час на виконання робіт відкоригований використовуючи коефіцієнти, які враховують умови роботи. Значення коефіцієнта $k_{y}$ наведено у таблиці 3.

3 врахуванням коригуючих коефіцієнтів час виконання робіт становитиме 179,9 хв або 3,0 год. Для вказаних робіт підготовчо-заключний час $\left(t_{\Pi-3}\right)$ згідно до [13] становить $3,5 \% ; t_{O б с}-2,5 \%, t_{B}-$ $3,6 \%$ та $t_{O c}-2,4 \%$ від оперативного часу.

Таким чином, за залежністю (5), розрахований оперативний час на виконання ТО-20000 для автобуса А22112 становитиме 3,0 год, а норматив трудомісткості робіт ТО-20000, за залежністю (2) становитиме 3,36 люд.-год.

Таблиця 3 - Значення коефіцієнту $k_{y}$.

\begin{tabular}{|l|c|c|}
\hline $\begin{array}{c}\text { Місце виконання } \\
\text { робіт }\end{array}$ & Положення працівника & Значення коефіцієнту $k_{y} \cdot$ \\
\hline $\begin{array}{l}\text { Моторний відсік } \\
\text { зверху }\end{array}$ & Стоячи із зігнутим корпусом & 1,1 \\
\hline Знизу автобуса & $\begin{array}{c}\text { Стоячи, роботи виконуються при } \\
\text { стельовому положенні }\end{array}$ & 1,3 \\
\hline Салон автобуса & Стоячи & 1,0 \\
\hline Місце водія & Сидячи & 1,0 \\
\hline Збоку автобуса & Стоячи & 1,0 \\
\hline
\end{tabular}

\section{ОБГОВОРЕННЯ РЕЗУЛЬТАТІВ ДОСЛІДЖЕНЬ}

Відповідно до нормативів наведених у $[2,15,16]$ для автобусів середнього класу трудомісткість ТО-1 становить 5,8 ...7,5 люд.-год. Співставляючи регламенти робіт 3 ТО-1 для сучасного транспортного засобу наведені у [14] та [16], відмічається значне зменшення їх переліку та обсягів. Так норма часу, отримана розрахунком, відрізняється від норм трудомісткості понад $40 \%$. Таким чином, зважаючи на реальні трудомісткості робіт з обслуговування аналогічних автобусів малого та середнього класів можна стверджувати про раціональність запропонованої методики. 


\section{ВИСНОВОК}

Розрахунки трудомісткості виконання робіт за запропонованою методикою отримання технічно обгрунтованих норм часу окремих видів робіт 3 технічного обслуговування колісних транспортних засобів свідчать про доцільність ії практичного застосування. Отримані результати вказують на необхідність продовження досліджень, для вдосконалення даного методу, а також обгрунтування часу виконання елементарних операцій, 3 врахуванням складності конструкції транспортного засобу та кваліфікації виконавців.

\section{ПЕРЕЛІК ДЖЕРЕЛ ПОСИЛАННЯ}

1. Правила надання послуг з технічного обслуговування і ремонту колісних транспортних засобів, затверджені наказом Міністерства інфраструктури України № 615 від 28.11.2014, зареєстровані в Міністерстві юстиції України від 17 грудня 2014 за № 1609/26386.

2. Положення про технічне обслуговування i ремонт дорожніх транспортних засобів автомобільного транспорту затверджене наказом Міністерства транспорту України № 102 від 30.03.1998, зареєстровані в Міністерстві юстиції України від 28 квітня 1998 за № 268/2708.

3. Мошковський С.О. Коригування питомих трудомісткостей ТО і ремонту легкових автомобілів під час технологічного розрахунку СТО / С.О. Мошковський, В.І. Павлюк, В.М. Дембіцький // Сучасні технології в машинобудуванні та транспорті. Науковий журнал - Луцьк: Луцький НТУ, 2017, № 1 (8). - с. 94 - 99.

4. Ощепков П. П., Храпова М. Ю. Модель расчёта трудоёмкости работ по техническому обслуживанию и ремонту автомобилей // Вестник евразийской науки. 2016. №3 (34). URL: https://cyberleninka.ru/article/n/model-raschyota-trudoyomkosti-rabot-po-tehnicheskomu-obsluzhivaniyu-iremontu-avtomobiley (дата обращения: 23.10.2020).

5. Сергеева А. Г. Анализ методов технологического расчета предприятий автосервиса / А. Г. Сергеева, М. В. Полуэктов. - Текст : непосредственный // Молодой ученый. - 2017. - № 23 (157). - С. 157-159. - URL: https://moluch.ru/archive/157/44128/ (дата обращения: 23.10.2020).

6. Тамер О.С. Разработка производственной программы при организации технологических процессов на участках УМР // Вестник ВУиТ. 2019. №3. URL: https://cyberleninka.ru/article/n/razrabotka-proizvodstvennoy-programmy-pri-organizatsii-tehnologicheskihprotsessov-na-uchastkah-umr (дата обращения: 23.10.2020).

7. Козлов А.В. Производственные программы по видам технического обслуживания и технического ремонта с учетом принятого режима работы автотранспортного предприятия // Вестник ВУиТ. 2019. №3. URL: https://cyberleninka.ru/article/n/proizvodstvennye-programmy-po-vidamtehnicheskogo-obsluzhivaniya-i-tehnicheskogo-remonta-s-uchetom-prinyatogo-rezhima-raboty (дата обращения: 23.10.2020).

8. Кириллов А. В. Исследование объемов работ по техническому обслуживанию и ремонту автомобильного транспорта // Научно-методический электронный журнал «Концепт». - 2016. - Т. 2. C. 431-435. - URL: http://e-koncept.ru/2016/46104.htm.

9. Мастепан С. М. Створення системи нормативного забезпечення процесів технічного обслуговування та ремонту транспортних засобів / С. М. Мастепан // Вісник Нац. техн. ун-ту "ХПІ" : зб. наук. пр. Темат. вип. : Автомобіле- та тракторобудування. - Харків : НТУ "ХПІ". - 2012. - № 64 (970). - С. 50-57.

10. Волков В. П. Формування напрямків розвитку нормативного забезпечення виробничих процесів на ПАТ / В. П. Волков, С. М. Мастепан, В. Ю. Рижова, І. М. Фоменко // Наукові нотатки. 2016. - Вип. 55. - С. 59-63. - Режим доступу: http://nbuv.gov.ua/UJRN/Nn 2016 5513

11. Нестеренко С.А., Агєєва І.В., Сурженко Н.В. Організація виробництва: Нормування праці. Навчальний посібник. URL: http://feb.tsatu.edu.ua/ebook/mn/ov/page5.html

12. Общестроительные нормативы времени на слесарною обработку деталей и слесарносборочные работы по сборке машин. Мелкосерийное и единичное производство. Изд. 2-е, М., «Машиностроение», 1974, 220 с (ЦБПНТ при НИИТ труда).

13. РД 03112178-1023-99. Сборник норм времени на техническое обслуживание и ремонт легковых, грузовых автомобилей и автобусов. Том 1. Москва $2005 . \quad$ URL: http://gostrf.com/normadata/1/4293846/4293846166.htm

14. Автобус міський А22112. Настанова щодо експлуатування. А22112-0000010-20 НЕ. Луцьк, $2017,155 \mathrm{c}$. 
15. ОНТП-01-91 [Електронний ресурс]. Общесоюзные нормы технологического проектирования предприятий автомобильного транспорта. Минавтотранс РСФСР - М.: Росавтотранс, 1991. URL: http://ventportal.com/ua/node/468.

16. Нормативы численности рабочих, занятых техническим обслуживанием и текущим ремонтом подвижного состава автомобильного транспорта. - M., 1988, 207 с. URL: https://meganorm.ru/Data2/1/4293846/4293846556.htm

\section{REFERENCES}

1. Pravyla nadannia posluh $\mathrm{z}$ tekhnichnoho obsluhovuvannia i remontu kolisnykh transportnykh zasobiv (2014), zatverdzheni nakazom Ministerstva infrastruktury Ukrainy № 615 vid 28.11.2014, zareiestrovani v Ministerstvi yustytsii Ukrainy vid 17 hrudnia 2014 za № 1609/26386.

2. Polozhennia pro tekhnichne obsluhovuvannia i remont dorozhnikh transportnykh zasobiv avtomobilnoho transportu (1998) zatverdzhene nakazom Ministerstva transportu Ukrainy № 102 vid 30.03.1998, zareiestrovani v Ministerstvi yustytsii Ukrainy vid 28 kvitnia 1998 za № 268/2708.

3. Moshkovskyi S.O., P avliuk V.I., Dembitskyi V.M. (2017) Koryhuvannia pytomykh trudomistkostei TO i remontu lehkovykh avtomobiliv pid chas tekhnolohichnoho rozrakhunku STO. Suchasni tekhnolohii v mashynobuduvanni ta transporti. Naukovyi zhurnal, 1 (8), 94-99.

4. Oshchepkov P. P., Khrapova M. Yu. (2016) Model raschyota trudoyomkosti rabot po tekhnicheskomu obsluzhyvaniyu i remontu avtomobiley. Vestnik evrazyiskoi nauki, 3 (34). URL: https://cyberleninka.ru/article/n/model-raschyota-trudoyomkosti-rabot-po-tehnicheskomu-obsluzhivaniyu-iremontu-avtomobiley

5. Serheeva A. H., Poluektov M. V. (2017) Analiz metodov tekhnolohycheskoho rascheta predpriyatiyi avtoservisa. Tekst : neposredstvennyy, Molodoy uchenyy, 23 (157), 157-159. URL: https://moluch.ru/archive/157/44128/

6. Tamer O.S. (2019) Razrabotka proizvodstvennoy prohrammy pri orhanyzatsyi tekhnolohycheskikh protsessov na uchastkakh UMR. Vestnyk VUyT, 3. URL: https://cyberleninka.ru/article/n/razrabotka-proizvodstvennoy-programmy-pri-organizatsii-tehnologicheskihprotsessov-na-uchastkah-umr

7. Kozlov A.V. (2019) Proyzvodstvennye prohrammy po vidam tekhnicheskoho obsluzhyvaniya i tekhnicheskoho remonta s uchetom priniatoho rezhyma raboty avtotransportnoho predpriyatiya. Vestnik VUiT, 3. URL: https://cyberleninka.ru/article/n/proizvodstvennye-programmy-po-vidam-tehnicheskogoobsluzhivaniya-i-tehnicheskogo-remonta-s-uchetom-prinyatogo-rezhima-raboty

8. Kyryllov A. V. (2016) Issledovaniye obyemov rabot po tekhnicheskomu obsluzhyvaniyu i remontu avtomobilnoho transporta. Nauchno-metodicheskiy elektronnyy zhurnal «Kontsept», T. 2., 431435. URL: http://e-koncept.ru/2016/46104.htm

9. Mastepan S. M. (2012) Stvorennia systemy normatyvnoho zabezpechennia protsesiv tekhnichnoho obsluhovuvannia ta remontu transportnykh zasobiv. Visnyk Nats. tekhn. un-tu "KhPI" : zb. nauk. pr. Temat. vyp. : Avtomobile- ta traktorobuduvannia, 64 (970), 50-57.

10. Volkov V. P., Mastepan S. M., Ryzhova V. Yu., Fomenko I. M. (2016) Formuvannia napriamkiv rozvytku normatyvnoho zabezpechennia vyrobnychykh protsesiv na PAT. Naukovi notatky. Vyp. 55, 59-63. URL: http://nbuv.gov.ua/UJRN/Nn_2016_55_13

11. Nesterenko S.A., Ahieieva I.V., Surzhenko N.V. Orhanizatsiia vyrobnytstva: Normuvannia pratsi. Navchalnyi posibnyk. URL: http://feb.tsatu.edu.ua/ebook/mn/ov/page5.html

12. Obshchestroitelnye normativy vremeni na slesarnoyu obrabotku detalei i slesarno-sborochnye raboty po sborke mashyn. Melkoseryynoe i edinichnoe proizvodstvo (1974) Izd. 2-e, - M.: Mashynostroenie(TsBPNT pri NIIT truda). URL: https://meganorm.ru/Index2/1/4293738/4293738245.htm

13. RD 03112178-1023-99. (1999) Sbornik norm vremeni na tekhnicheskoe obsluzhyvanie i remont lehkovykh, hruzovykh avtomobilei i avtobusov. Tom $1 . \quad$ URL: http://gostrf.com/normadata/1/4293846/4293846166.htm

14. Avtobus miskyi A22112. (2017) Nastanova shchodo ekspluatuvannia. A22112-0000010-20 NE., - Lutsk, 155.

15. ONTP-01-91 (1991) Obshchesoiuznie normy tekhnolohicheskoho proektirovaniia predpriiatyi avtomobylnoho transporta, - M.: Rosavtotrans. URL: http://ventportal.com/ua/node/468

16. Normativy chislennosti rabochikh, zaniatykh tekhnicheskim obsluzhyvaniem i tekushchim remontom podvizhnoho sostava avtomobilnoho transporta (1988), - M., $207 . \quad$ URL: https://meganorm.ru/Data2/1/4293846/4293846556.htm 


\begin{abstract}
$V$. Dembitskyi, V. Pavliuk. Determination of the norms of time for maintenance of the vehicle for the formation of labor intensity of work.

The paper considers topical issues of determining the norms of time for maintenance and repair of vehicles to form the labor intensity of maintenance and current repair of the rolling stock of road transport enterprises, which will be used during their technological calculation. On the basis of the existing norms of time for performing various types of work, a graph of technical maintenance (repair) of a car was proposed, according to which a methodology for determining the norms of time and labor intensity of technical influences on a car was developed. The graph of maintenance (repair) of vehicles serves as a graphical model for further calculations of time norms and provides the transition from the object of influence to the elementary operations. This approach allows you to distribute the elementary operations and take into account the peculiarities of their implementation. Developed a method contributes to the further development of methods for determining the labor intensity of maintenance for the technological calculation of road transport enterprises. The analysis of the values of the labor intensity of vehicle maintenance is carried out. On the example of carrying out routine maintenance of the low order for a bus using methods of analyzing the costs of working time and using the time norms for locksmith operations, an approximate calculation of its total labor intensity was carried out. The results obtained indicate a reduction in the time for performing bus maintenance operations, and, accordingly, a decrease in the established labor intensity of about $40 \%$ compared to the normative value.
\end{abstract}

Key words: maintenance, labor intensity, technological calculation, motor transport company.

ДЕМБІЦЬКИЙ Валерій Миколайович, кандидат технічних наук, доцент кафедри автомобілів і транспортних технологій, Луцький НТУ, e-mail: dvm2@ meta.ua. http://orcid.org/0000-0002-1006-9218

ПАВЛЮК Василь Іванович, кандидат технічних наук, доцент кафедри автомобілів і транспортних технологій, Луцький НТУ, e-mail: pavliuk_v.i@ukr.net. . http://orcid.org/0000-0002-0678$\underline{3566}$

Valerii DEMBITSKYI, PhD. in Engineering, Assoc. Professor of Motor Cars and Transport Technologies Department, Lutsk National Technical University, e-mail: dvm2@meta.ua. http://orcid.org/0000-0002-1006-9218

Vasyl PAVLIUK, PhD. in Engineering, Assoc. Professor of Motor Cars and Transport Technologies Department, Lutsk National Technical University, e-mail: pavliuk_v.i@ukr.net. http://orcid.org/0000-0002$\underline{0678-3566}$

DOI 10.36910/automash.v2i15.388 